Artic le Review

\title{
Dinamika Interaksi Reseptor ACE2 dan SARS-CoV-2 Terhadap Manifestasi Klinis COVID-19
}

\author{
Risma Ikawaty ${ }^{1 *}$ \\ ${ }^{1}$ Fakultas Kedokteran, Universitas Surabaya, Surabaya-Indonesia \\ * corresponding author: risma.ikawaty@staff.ubaya.ac.id
}

\begin{abstract}
A human severe acute respiratory syndrome coronavirus 2 (SARS-CoV-2) is known to be responsible for coronavirus disease 2019 (COVID-19). Pulmonary complications have been considered as the classical clinical manifestations until symptoms on the extra-pulmonary organs may also occurrecently, which might be linked to the presence of the angiotensin-converting enzyme 2 (ACE2) receptor. This article evaluates the clinical manifestation of COVID-19 and the presence of ACE2 receptors by looking at its interaction with SARS-CoV-2. Twenty-seven articles in English have been selected through search engines PubMed and Google Scholar byusing specific keywords. These articles include researchjournals, case reports, systematic reviews and meta-analyses, and textbooks. Pathogenesis of COVID-19 begins with the binding of spike protein SARS-CoV-2 to the ACE2 receptor of host cells. Clinical manifestation of COVID-19 is no longer limited to the pulmonary system but also extra-pulmonary systems since ACE2 receptors are abundantly distributed on the other organs. Further, genetic variations of region binding protein of viral spike protein and ACE2 receptor may predispose clinical manifestation of COVID19. The dynamic interplay between SARS-CoV-2 and receptor ACE2 has great implications for the clinical symptoms. Genetic variation of spike protein SARS-CoV-2 plays a role not only for crosstransmission but also its virulence, while the genetic variation of human receptor ACE2 influences its susceptibility or resistance against the infection.
\end{abstract}

Keywords: ACE2 receptor, coronavirus diseases-19, clinical manifestation, SARS-CoV-2, genetic variation

Abstrak - Virus severe acute respiratory syndrome coronavirus 2 (SARS-CoV-2) merupakan penyebab utama dari coronavirus disease 2019 (COVID-19). Komplikasi pernapasan diangap sebagaigejala klinis klasik hingga akhirnya timbul berbagai manifestasi klinis di organ lain sebagai gejala awal COVID19. Hal ini kemudian dihubungkan dengan reseptorangiotensin-converting enzyme 2 (ACE2). Artikel ini mengevaluasi manifestasi klinis yang disebabkan interaksi antara reseptor ACE2 dan SARS-CoV-2. PubMed dan Google Scholar digunakan untuk mencari artikel dengan kata kunci yang spesifik untuk COVID-19, SARS-CoV-2, reseptor ACE2, variasi genetik, dan manifestasi klinisnya. Dua puluh tujuh artikel berbahasa Inggris yang digunakan termasuk jurnal penelitian, laporan kasus, systematic review, meta-analysis, dan buku teks. Patogenesis COVID19 dimulaidengan ikatan protein Spike SARSCoV-2 dan reseptor ACE2. Studi memperlihatkan bahwa reseptor ACE2 ditemui di berbagai jaringan/organ selain organ sistem respirasi sehingga memperlihatkan gejala klinis yang berbeda. Selain itu variasi genetik yang terdapat pada protein spike dari virus dan reseptor ACE2 juga merupakan faktor penting pada terjadinya COVID19. Penulis menyimpulkanbahwa dinamika interaksi antara reseptor ACE2 dan protein spike SARS-CoV-2 termasuk variasi genetic, keduanya memegang peranan penting terhadap suseptibilitas/resistensi dan manifestasi klinis COVID19.

Kata kunci: coronavirus diseases-19, manifestasi klinis, reseptor ACE2, SARS-CoV-2, variasi genetik.

\section{PENDAHULUAN}

Coronavirus Diseases-19 (COVID-19) yang disebabkan oleh infeksi severe acute respiratory syndrome coronavirus 2 (SARS-CoV-2) muncul pertama kali di Wuhan Cina pada penghujung tahun 2019. Penyebaran global yang cepat disertai gejala klinis yang berat membuat World Health Organisation menetapkan status pandemi COVID19 pada 11 Maret 2020 hingga saat ini. Kasus positif SARS-CoV-2 pada pertengahan Mei 2020 dilaporkan telah mencapai lebih dari 4 juta orang dari 215 negara, dengan angka kematian 6.8\% (https://www.who.int). Gambar 1 menunjukkan kronologis awal timbulnya COVID-19 hingga ditetapkan status pandemi. 


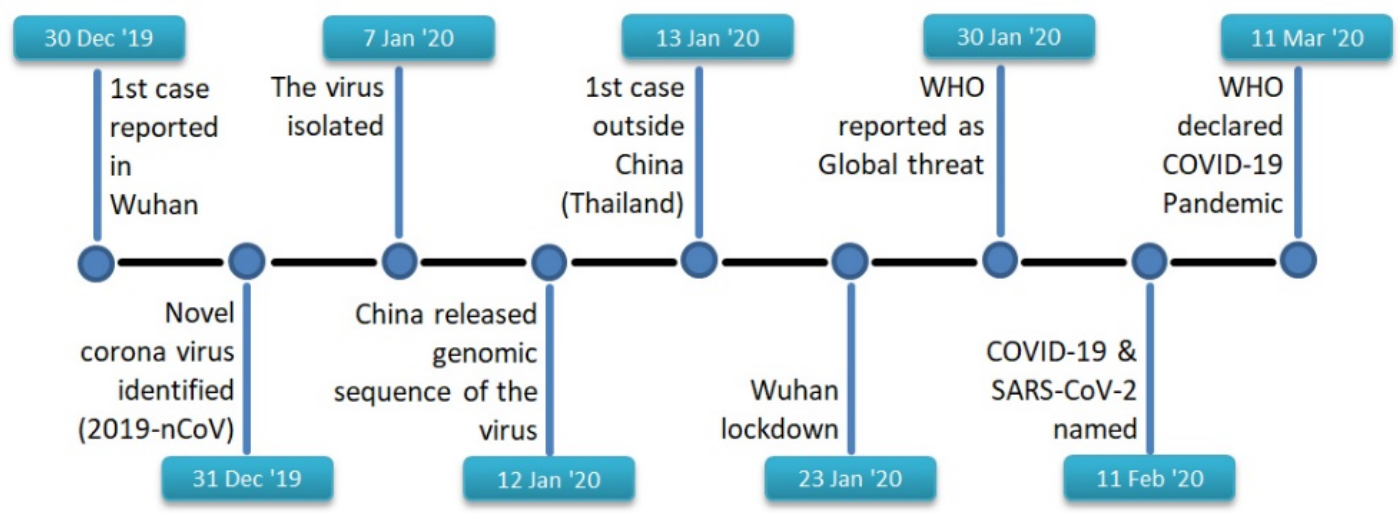

Gambar 1. Kronologis perjalanan COVID-19 sejak kemunculan pertama kali hingga ditetapkan sebagai status pandemi oleh W.H.O.

COVID-19 menunjukkan gejala gangguan pernapasan akut yang mirip dengan Severe Acute Respiratory Syndrome (SARS) tahun 2002-2003 dan Middle East Respiratory Syndrome (MERS) tahun 2012 [1]. Angka kejadian yang tinggi disertai manifestasi klinis yang berat hingga kematian, sayangnya tidak disertai dengan ketersediaan vaksin dan obat yang tepat. Saat ini penelitian tentang SARS-CoV-2 dilakukan secara masif guna mempelajari asal, struktur dan karakteristik virus, termasuk mengeksplorasi sekuen genomnya. Upaya ini bertujuan agar deteksi dini dan diagnosis dapat dilakukan cepat dan tepat sehingga tindakan intervensi dapat segera dilakukan, selain itu juga untuk menemukan kandidat vaksin yang efektif dan target terapi tepat.

ACE2 merupakan homolog dari angiotensin-converting enzyme (ACE) yang bekerja menyeimbangkan fungsi ACE. Rasio ACE/ACE2 di jaringan berperan untuk mengaktivasi sistem renin-angiotensin-aldosterone (RAAS) yang mengatur jalur keseimbangan antara proinflammatory dan pro-fibrotic, dan anti-inflammatory dan anti-fibrotic pada proses peradangan dan kerusakan jaringan. Satu penelitian melaporkan terjadinya peningkatan ekspresi ACE2 di jaringan endotel kapiler interstisial dan glomerulus pada kerusakan ginjal, dan kemudian menyimpulkan bahwa ACE2 dianggap sebagai penanda kerusakan jaringan [2].

Saat pandemi SARS tahun 2002-2003, penelitian menunjukkan adanya interaksi antara SARS-CoV-1 dan ACE2 yang berperanan penting dalam mekanisme terjadinya penyakit. Patomekanisme penyakit diawali oleh interaksi ACE2 dengan protein spike SARS-CoV-1 di regio spesifik, diikuti oleh fusi membran virus dengan membran sel inang. Peneliti menggunakan mencit dengan gen reseptor ACE2 yang sudah di "knockout” yang kemudian dipaparkan dengan SARS-CoV-1. Hasil penelitian menunjukkan titer virus yang sangat rendah dan perubahan patologi di jaringan paru-paru yang sangat minimal dibandingkan dengan mencit yang normal tanpa intervensi (titervirus lebih tinggi dan kerusakan jaringan yang lebih berat). Data ini dengan jelas menunjukkan bahwa reseptor ACE2 sangat krusial dalam proses infeksi SARS-CoV-1. Selain itu, ACE2 juga berfungsi sebagai regulator negatif terhadap kerusakan jaringan. Penelitian yang sama menggunakan mencit normal yang terpapar SARS-CoV-1 menunjukkan adanya penurunan ekspresi ACE2 akibat proses internalisasi yang disebabkan oleh adanya ikatan antara reseptor ACE2 dan SARS-CoV-1. Penurunan ekspresi ACE2 akan menghambat efek proteksi ACE2 yang pada akhirnya berkontribusi terhadap keparahan gejala klinis di paru-paru [3].

Belajar dari SARS, hal serupa pun dilakukan terhadap COVID-19. Penelitian terkini menemukan adanya peran reseptor ACE2 terhadap infeksi SARS-CoV-2. Artikel ini akan menelaah peran reseptor ACE2 pada infeksi SARS-CoV-2 dan hubungannya dengan manifestasi klinis yang timbul, beserta kemungkinan target terapi COVID-19. 
METODE

Penulis melakukan pencarian artikel melalui PubMed, Google Scholar dan textbook Mikrobiologi menggunakan kata kunci "COVID19", "SARS-CoV-2", "ACE2", "clinical manifestation", "respiratory system", "nervous system", "eye", "renal", "gastrointestinal", "cardiovascular", "skin", "polymorphism", "genetic variation", "spike protein" Artikel yang dipilih berupa jurnal penelitian, case report, systematic review dan meta-analysis, narrative review terfokus pada COVID19, SARS-COV-2, manifestasi klinis, reseptor ACE2, variasi genetik, protein spike. Pencarian literatur dibatasi pada publikasi berbahasa Inggris. Total 27 artikel yang dimasukkan ke dalam review ini.

\section{HASIL}

Pada awal terjadinya outbreak, diyakini bahwa infeksi SARS-CoV-2 serupa dengan SARS yang hanya memberikan implikasi klinis sesuai dengan port $d$ entrée virus pada saluran pernapasan dan saluran pencernaan saja, dimana ekspresi ACE2 di kedua organ tersebut sangat dominan [4,5]. Saat ini manifestasi klinis COVID-19 tidak lagi memperlihatkan gejala klasik saja seperti demam, batuk, dan sesak napas, tapi semakin beragam. Data tentang gejalagejala klinis tidak spesifik tersebut diambil dari berbagai laporan kasus pasien yang positif terinfeksi SARS-CoV-2, seperti yang tampak pada Tabel 1 berikut ini.

Tabel 1

Manifestasi Klinis yang Disebabkan Oleh Infeksi SARS-CoV-2

\begin{tabular}{|c|c|c|c|}
\hline No. & $\begin{array}{c}\text { Target Organ/Sistem } \\
\text { Organ }\end{array}$ & Manifestasi Klinis & Referensi \\
\hline 1 & Sistem saraf & $\begin{array}{l}\text { Gangguan perasa dan penghidu, nyeri } \\
\text { kepala, mual, muntah }\end{array}$ & $(6-9)$ \\
\hline 2 & Mata & Konjungtivitis & $(10-12)$ \\
\hline 3 & Ginjal & $\begin{array}{l}\text { Acute Kidney Injury (AKI), proteinuria, } \\
\text { hematuria }\end{array}$ & (13) \\
\hline 4 & Saluran pencernaan & Mual, muntah, diare, nyeri abdomen & (14) \\
\hline 5 & Kardiovaskuler & $\begin{array}{l}\text { Miokarditis, infark miokard akut, gagal } \\
\text { jantung akut, kardiomiopati, disritmia, } \\
\text { tromboembolivena. }\end{array}$ & (15) \\
\hline 6 & Kulit & $\begin{array}{l}\text { Bercak kemerahan, biduran/kaligata, lenting } \\
\text { berisi cairan }\end{array}$ & (16) \\
\hline
\end{tabular}

Manifestasi klinis yang timbul pada berbagai organ tersebut diperkirakan sejalan dengan hasil penelitian terkini yang menunjukkan ekspresi ACE2 di berbagai organ seperti jantung, ginjal, kandung kemih, mata, dan sistem saraf termasuk otak (Tabel 2) $[17,18]$. Temuan ini mengindikasikan kemungkinan virus dapat menyebabkan kerusakan langsung pada jaringan yang mengandung reseptor ACE2. 


\section{Tabel 2}

Distribusi Reseptor ACE2 pada Jaringan/Organ Tubuh Manusia [2]

\begin{tabular}{|c|c|c|c|}
\hline No. & Organ/ Jaringan & Lokasi & $\begin{array}{c}\text { Intensitas ekspresi } \\
\text { ACE2 }\end{array}$ \\
\hline 1 & Paru-paru & Sel epitel bronkial, alveolus & Tinggi \\
\hline 2 & Saluran cerna & $\begin{array}{l}\text { Sel epitel esophageal, ileum, } \\
\text { jejenum, duodenum, kolon }\end{array}$ & Tinggi \\
\hline 3 & $\begin{array}{l}\text { Jantung dan } \\
\text { pembuluh darah }\end{array}$ & $\begin{array}{l}\text { Sel endotel pembuluh darah, } \\
\text { miokardium }\end{array}$ & Tinggi \\
\hline 4 & $\begin{array}{l}\text { Organ berotot } \\
\text { polos }\end{array}$ & Sel otot polos & Tinggi \\
\hline \multirow[t]{2}{*}{5} & Ginjal & Sel tubulus proximal, & Tinggi \\
\hline & & sel epitel parietal, podosit & Lemah \\
\hline 6 & Kulit & Lapisan epidermis & Tinggi \\
\hline 7 & Mulut, hidung & Lapisan mukosa & Tinggi \\
\hline 8 & Lemak & Visceral adiposa & Tinggi \\
\hline 9 & Hati & Duktus bilier & Tinggi \\
\hline 10 & Plasenta & $\begin{array}{l}\text { Tali pusat, placental villi pada } \\
\text { syncytiotrophoblast, } \\
\text { cytotrophoblast, endotel pembuluh } \\
\text { darah, sel otot polos, trophoblast } \\
\text { dan sel desidual. }\end{array}$ & Tinggi \\
\hline 11 & Otak & $\begin{array}{l}\text { Neuron, sel glia, endotel pembuluh } \\
\text { darah serebral }\end{array}$ & Tinggi \\
\hline
\end{tabular}

BAHASAN

SARS-CoV-2 termasuk dalam family coronaviridae yang mempunyai kemampuan rekombinasi yang sangat cepat, memiliki karakteristik mengandung material genetik ss-RNA, terdiri dari lapisan protein envelope (E), spike (S), membrane (M), dan nucleocapsid (N). Spike merupakan glikoprotein berbentuk tonjolan-tonjolan yang menyerupai mahkota yang berperanan penting dalam pathogenesis dengan bantuan reseptor sel tubuh yang spesifik $[19,20]$.

Invasi SARS-CoV-2 ke dalam sel inang dimulai oleh perlekatan glikoprotein spike pada reseptor angiotensin-converting enzyme (ACE2) dengan bantuan enzim transmembrane protease serine 2 (TMPRSS2) [21,22], yang dilanjutkan dengan fusi membran. RNA virus kemudian dilepaskan ke dalam sitoplasma sel inang dan replikasi material genetik dimulai. RNA yang sudah diperbanyak bersama dengan protein $\mathrm{E}$ dan $\mathrm{N}$ membentuk vesikel yang mengandung virion, menembus membran dan akhirnya keluar dari sel inang yang selanjutnya menginfeksi sel lain dan mengulangi siklus replikasi diatas $[19,20]$. 
Apabila kita melihat pada sistem renin-angiotensin-aldosterone, angiotensin II (ANG II) mempunyai efek meningkatkan tekanan darah dan inflamasi, meningkatkan kerusakan jaringan dan lapisan pembuluh darah. ACE2 berfungsi menghambat kerja ANG II dengan cara mengubah ANG II menjadi molekul lain yang memberikan efek berlawanan. Ketika SARS-CoV-2 berikatan dengan reseptor ACE2, hal ini menghambat fungsi normal ACE2 dalam meregulasi ANG II, akibatnya ANG II akan tersedia bebas untuk selanjutnya merusak jaringan.

Penelitian di tingkat molekuler yang melihat interaksi biokimia dan analisis struktur kristal menunjukkan adanya afinitas ikatan yang kuat antara protein spike SARS-CoV-1 dengan ACE2. Bila dilihat dari sekuen asam amino spike dari SARS-CoV-1 dan SARS-CoV-2 memiliki kemiripan hingga $76.5 \%$, begitu pula dengan tingkat homologi protein spike kedua virus yang tinggi. Salah satu sifat yang membedakan kedua virus ini adalah afinitas terhadap ACE2 dari receptor binding domain (RBD) protein Spike pada SARS-CoV-2 yang secara signifikan lebih kuat dibandingkan SARS-CoV-1 $[23,24]$. Hal ini menunjukkan bahwa SARS-CoV-2 memiliki risiko yang lebih tinggi dalam proses penyebarannya.

Gen ACE2 memiliki tingkat polimorfisme yang tinggi [25]. Cao et. al. melakukan analisis perbandingan variasi coding-region dan expression quantitative trait loci (eQTL) ACE2 dari berbagai populasi mencakup Asia Timur, Eropa, Amerika, Afrika, Asia Selatan, dan MixedAmerican. Hasil menunjukkan adanya variasi antara populasi. Populasi Asia Timur memperlihatkan frekuensi alel yang lebih besar disertai dengan ekspresi ACE2 jaringan yang lebih tinggi dibandingkan kelompok populasi yang lain. Studi ini memperlihatkan adanya perbedaan respon atau suseptibilitas terhadap infeksi SARS-CoV-2 dengan kondisi yang sama pada populasi yang berbeda [26]. Hussain et.al. menunjukkan variasi genetik pada reseptor ACE2 tidak hanya berkontribusi pada daya resistensi atau susepti bilitas tubuh terhadap infeksi coronavirus ini, tetapi juga pada manifestasi klinis yang muncul dan kecepatan penyembuhan. Dua alel gen ACE2 yaitu rs73635825 (S19P) dan rs143936283 (E329G), menunjukkan afinitas yang rendah terhadap protein spike dari SARS-CoV-2 sehingga memberikan efek resisten terhadap infeksi virus tersebut. Studi ini kemudian menyimpulkan bahwa variasi genetik di atas dapat digunakan untuk menentukan prognosis COVID-19 [27].

Pada awal terjadinya outbreak COVID-19, gejala klinis yang selalu menjadi acuan adalah batuk, demam, dan adanya kesulitan bernapas. Seiring dengan berjalannya waktu, berbagai laporan kasus memperlihatkan manifestasi klinis yang berbeda dan tidak spesifik pada pasien positif COVID-19 seperti yang terlihat pada Tabel 1 di atas. Apabila dihubungkan dengan tempat ditemukannya reseptor ACE2, tampak jelas bahwa ekspresi ACE2 terdistribusi di berbagai jaringan dan organ tubuh (Tabel 2). Akibatnya, mungkin saja apabila terjadi interaksi antara SARS-CoV-2 dengan reseptor ACE2 pada jaringan atau organ tertentu, manifestasi klinis akan sesuai dengan jaringan/organ yang terkena. Tentu saja ada beberapa faktor lain yang ikut mempengaruhi timbulnya manifestasi klinis serta tingkat keparahannya seperti usia, jenis kelamin, obesitas, ada tidaknya penyakit penyerta (komorbid), dan pasien yang mendapatkan pengobatan immunosuppressive [2].

Keterbatasan pada jurnal penelitian dan laporan kasus yang digunakan pada article review ini secara garis besar adalah minimnya jumlah dan variasi sampel yang digunakan sehingga informasi mengenai ekspresi reseptor ACE2, fungsi dan mekanisme kerjanya pada berbagai organ masih belum banyak diketahui. Oleh karena itu diperlukan penelitian lebih lanjut untuk mengetahui lebih jauh lagi bagaimana patomekanisme yang terjadi pada tiap organ dengan menggunakan sampel yang lebih banyak. Menarik pula untuk diteliti apakah jaringan/organ yang kaya akan reseptor ACE2 akan memberikan respon yang sama bila terinfeksi SARS-CoV-2.

\section{SIMPULAN}

COVID-19 diawali oleh ikatan antara reseptor ACE2 pada sel tubuh manusia dengan protein spike dari SARS-CoV-2 segera setelah terjadi infeksi. Penelitian multisenter memperlihatkan bahwa reseptor ACE2 ditemui di berbagai jaringan atau organ selain sistem 
respirasi sehingga memperlihatkan gejala klinis yang tidak spesifik untuk COVID19, sesuai dengan tempat infeksi ini berlangsung. Mutasi pada protein spike SARS-CoV-2 yang memungkinkan terjadinya transmisi dari hewan ke manusia, juga mampu mengubah sifat virus menjadi lebih virulen. Selain itu variasi genetik pada reseptor ACE2 pun memegang peranan penting dalam suseptibilitas dan resistensi terhadap infeksi SARS-CoV-2.

Pemahaman yang lebih dalam mengenai mekanisme interaksi antara reseptor ACE2 dan SARS-CoV-2 memberikan implikasi yang besar terhadap penanganan COVID-19. Dengan adanya gejala klinis yang tidak spesifik diharapkan klinisi untuk lebih berhati-hati dalam penanganan pasien untuk menghindari risiko terinfeksi virus ini.

\section{PUSTAKA ACUAN}

1. Tu YF, Chien CS, Yarmishyn AA, Lin YY, Luo YH, Lin YT, et al. A review of sars-cov-2 and the ongoing clinical trials. Int J Mol Sci. 2020;21(7).

2. Bourgonje AR, Abdulle AE, Timens W, Hillebrands J. Angiotensin-converting enzyme-2 (ACE2), SARS-CoV-2 and pathophysiology of coronavirus disease 2019 (COVID-19). J Pathol. 2020;

3. Kuba K, Imai Y, Rao S, Gao H, Guo F, Guan B, et al. A crucial role of angiotensin converting enzyme 2(ACE2) in SARS coronavirus-induced lung injury. Nat Med. 2005;11(8):875-9.

4. Jia HP, Look DC, Shi L, Hickey M, Pewe L, Netland J, et al. ACE2 Receptor Expression and Severe Acute Respiratory Syndrome Coronavirus Infection Depend on Differentiation of Human Airway Epithelia. J Virol. 2005;79(23):14614-21.

5. Hamming I, Timens W, Bulthuis MLC, Lely AT, Navis GJ, van Goor H. Tissue distribution of ACE2 protein, the functional receptor for SARS coronavirus. A first step in understanding SARS pathogenesis. J Pathol. 2004;203(2):631-7.

6. Li YC, Bai WZ, Hashikawa T. The neuroinvasive potential of SARS-CoV2 may play a role in the respiratory failure of COVID-19 patients. J Med Virol. 2020;92(6):552-5.

7. Baig AM, Khaleeq A, Ali U, Syeda H. Evidence of the COVID-19Virus Targeting the CNS: Tissue Distribution, Host-Virus Interaction, and Proposed Neurotropic Mechanisms. ACS Chem Neurosci. 2020;11.

8. Yeager A. Lost Smell and Taste Hint COVID-19 Can Target the Nervous System. The Scientist Magazine. 2020;

9. Klopfenstein T, Kadiane-Oussou NJ, Toko L, Royer PY, Lepiller Q, Gendrin V, et al. Features of anosmia in COVID-19. Med Mal Infect [Internet]. 2020;4-7. Available from: https://doi.org/10.1016/j.medmal.2020.04.006

10. Wu P, Duan F, Luo C, Liu Q, Qu X, Liang L, et al. Characteristics of Ocular Findings of Patients With Coronavirus Disease 2019 (COVID-19) in Hubei Province, China. JAMA Ophthalmol. 2020;138(5):575-8.

11. Loon SC, Teoh SCB, Oon LLE, Se-Thoe SY, Ling AE, Leo YS, et al. The severe acute respiratory syndrome coronavirus in tears. Br J Ophthalmol. 2004;88(7):861-3.

12. Man X, Hongda Z, Xiaoguang N. COVID-19 patient firstly visiting eye doctor due to tarsadenitis and subconjunctival hemorrhage : A case report. Chinese J Exp Ophthalmol. 2020;(04).

13. Su H, Yang M, Wan C, Yi LX, Tang F, Zhu HY, et al. Renal histopathological analysis of 26 postmortem findings of patients with COVID-19 in China. Kidney Int [Internet]. 2020; Available from: https://doi.org/10.1016/j.kint.2020.04.003

14. Cheung KS, Hung IF, Chan PP, Lung KC, Tso E, Liu R, et al. Gastrointestinal Manifestations of SARS-CoV-2 Infection and Virus Load in Fecal Samples from the Hong Kong Cohort and Systematic Review and Meta-analysis. Gastroenterology [Internet]. 2020; Available from: https://doi.org/10.1053/j.gastro.2020.03.065

15. Long B, Brady WJ, Koyfman A, Gottlieb M. Cardiovascular complications in COVID-19. Am J Emerg Med [Internet]. 2020;4-7. Available from: 
https://doi.org/10.1016/j.ajem.2020.04.048

16. Recalcati S. Cutaneous manifestations in COVID-19: a first perspective. J Eur Acad Dermatol Venereol. 2020;

17. Muus C, Luecken MD, Eraslan G, Waghray A, Heimberg G, Sikkema L, et al. Integrated analyse s of single-cell atlases reveal age, gender, and smoking status associations with cell type-specific expression of mediators of SARS-CoV-2 viral entry and highlights inflammatory programs in putative target cells. bioRxiv. 2020;

18. Baraniuk C. Receptors for SARS-CoV-2Present in Wide Variety of Human Cells. The Scientist Magazine. 2020 Apr;

19. Black JG, Black L. Microbiology Principles and Explorations. 9th ed. Wiley; 2015.

20. Tortora GJ, Funke BR, Case CL. Microbiology an Introduction. 12th ed. Pearson; 2016. 390-419 p.

21. Hoffmann M, Kleine-Weber H, Schroeder S, Krüger N, HerrlerT, Erichsen S, et al. SARSCoV-2 Cell Entry Depends on ACE2 and TMPRSS2 and Is Blocked by a Clinically Proven Protease Inhibitor. Cell. 2020;181(2):271-280.e8.

22. Magrone T, Magrone M, Jirillo E. Focus on Receptors for Coronaviruses with Special Reference to Angiotensin-converting Enzyme 2 as a Potential Drug Target - A Perspective. Endocr Metab Immune Disord Drug Targets. 2020;20(00):1-5.

23. Li F, Li W, Farzan M, Harrison SC. Structural biology: Structure of SARS coronavirus spike receptor-binding domain complexed with receptor. Science (80-). 2005;309(5742):1864-8.

24. Xu X, Chen P, Wang J, Feng J, Zhou H, Li X, et al. Evolution of the novel coronavirus from the ongoing Wuhan outbreak and modeling of its spike protein for risk of human transmission. Sci China Life Sci. 2020;63(3):457-60.

25. Luo Y, LiU C, Guan T, Li Y, Lai Y, Li F, et al. Association of ACE2 genetic polymorphisms with hypertension-related target organ damages in south Xinjiang. Hypertens Res [Internet]. 2019;42(5):681-9. Available from: http://dx.doi.org/10.1038/s41440-0180166-6

26. Cao Y, Li L, Feng Z, Wan S, Huang P, Sun X, et al. Comparative genetic analysis of the novel coronavirus (2019-nCoV/SARS-CoV-2) receptor ACE2 in different populations. Cell Discov [Internet]. 2020;6(1):4-7. Available from: http://dx.doi.org/10.1038/s41421-0200147-1

27. Hussain M, Jabeen N, Raza F, ShabbirS, Baig AA, Amanullah A, et al. Structural variations in human ACE2 may influence its binding with SARS-CoV-2 spike protein. J Med Virol. 2020;(January). 